\title{
The status and methodological interpretation of terminological phraseological units in scientific technical texts
}

\author{
Olga Nikolenko* ${ }^{* 1}$ and Elena Shapovalova ${ }^{1}$ \\ ${ }^{1}$ Don State Technical University, 1, Gagarin sq., 344003, Rostov-on-Don, Russia,
}

\begin{abstract}
The article reveals the problem of the status of terminological phraseological units as meaning-forming units of popular science texts of mechanical engineering, which is relevant for the modern methodology of the Russian language as a foreign language, their functional capabilities are being determined that let them to participate in the structuring of speech images and transmit subjective intentions through speech impact. The authors develop the idea that phraseological units are conventional means of creating imagery with a certain amount of preserving their internal form, and they prove that scientific phraseological units, increasing the speech emotionality, play a special role in the implementation of suggestions and pragmatic goals of communication, because they contain the amount of scientific information, much more rather than in options without them. All this explains the using of phraseological units in both spoken language and written scientific texts: thanks to these formal shells, the authors focus the attention of their recipients on the key points of the study. Due to intentionality, phraseological units are the means of worldview objectification of their addressee.
\end{abstract}

\section{Introduction}

It is accepted to consider that the texts of the scientific style of speech are not characterized by a bipartite semantic filling, since their very nature requires clarity and objectivity in presentation. However, on closer review of the designated unit, one can see that in almost each of them there is a subjective author's position, transmitted by a special intonation in the spoken presentation, in the written presentation - by the emphasis (special lexical and syntactic means). In this article, the authors aim to describe some scientific phraseological units as the means of creating and transmitting a veiled self-position in the scientific text of the engineering focus and to suggest the solution of methodological problems arising when teaching foreigners the scientific style of speech with an emphasis on the functioning of phraseological units in it.

Moreover, by virtue of its metaphorical nature, phraseological units simultaneously convey both a communicative and informational filling, and realize a pragmatic effect, by which we mean a speech influence on one or a group of subjects using verbal and non-

* Corresponding author: olganikolenko15011977@,gmail.com 
verbal signs. This allows us to assert that phraseological units also perform a suggestive function: they unobtrusively force the addressee to accept the system of his scientific views and induce him to a specific behavior.

Some researchers dealing with the methods of teaching foreign students believe that the introduction into practice of the concepts and methods of modern phraseological theory at the preparatory stage is inappropriate, explaining the fact that in the conditions of teaching intensification and its communicative focus, priority should be given to the common vocabulary. Accepting completely this position, we nevertheless believe that along with the indicated layer of lexicography, phraseological units that are frequently encountered in scientific speech should be introduced within the framework of the scientific style of speech, as many of them form the functional aspect of the language: they expand and enrich the semantic properties of the left and right environment and endow the whole statement with a meaningful subtext. In this connection some questions arise: how to teach phraseology? In a stylistic differentiation or outside of it? In a minimized or a full volume? It is difficult to find the answers to these questions in the available methodological literature, although some moments are somehow described in separate articles (E. Borisova, V. Devkina, E. Dibrova, V. Bondarenko, N. Telia, N. Sanskiy and others) $[1,2,5,7]$. Within the framework of this study, first of all the functional and methodological aspects of the pointed linguistic phenomenon is of interest, the study of these aspects expands the description of the structural and semantic possibilities of phraseological units in popular science texts (on the bases of lectures on mechanical engineering) and outline methodological ways of linguistic material presenting to a foreign audience.

\section{Materials and methods}

Highly specialized texts of a technical field (mainly lectures on mechanical engineering) served as a linguistic material for the proposed study, they were subjected to the methods of linguistic observation and description (when determining the status of emphatic models), to the comparative and contextual analysis (when identifying their functional features), to the method of continuous sample and statistical calculation (for the quantitative characteristic presentation of the indicated syntaxemes).

\section{Results}

Popular science literature is widely demanded by foreigners studying Russian with the aim to get education at Russian universities. This is explained, primarily, by the fact that it is such a type of literature that gives more opportunities for acquaintance with the advanced science achievements, which undoubtedly increase the students' interest both in the chosen specialty and in the Russian language as well.

However, when reading popular science publications, foreigners face certain difficulties, one of which is the interpretation of phraseological units. It is possible to distort the meaningful filling of the whole utterance due to a misunderstanding of these lexemes; and if we take into account that the phraseological unit contains a certain ideology in itself, then we can say that it represents both a personally noted and a national opinion about the world.

The phraseological composition of the Russian language is rich and varied. It has tens of thousands of phraseological units. They, like free words, differ in stylistic coloring.

Let us present in the table the classification of phraseological units according to their use in various styles of speech. 
Table 1. Types of phraseological units.

\begin{tabular}{|l|l|l|}
\hline \multicolumn{1}{|c|}{$\begin{array}{c}\text { phraseological unit } \\
\text { type }\end{array}$} & \multicolumn{1}{|c|}{ description } & \multicolumn{1}{|c|}{ example } \\
\hline $\begin{array}{l}\text { Stylistically neutral } \\
\text { phraseological units }\end{array}$ & $\begin{array}{l}\text { call objects, phenomena, actions } \\
\text { without any assessment }\end{array}$ & $\begin{array}{l}\text { more or less, to enter into } \\
\text { force, first of all, on their } \\
\text { part and others }\end{array}$ \\
\hline $\begin{array}{l}\text { Book } \\
\text { phraseological units }\end{array}$ & $\begin{array}{l}\text { used in scientific and official- } \\
\text { business styles of speech, often } \\
\text { used in written speech }\end{array}$ & $\begin{array}{l}\text { alpha and omega, stumbling } \\
\text { block, sealed book, lead to a } \\
\text { common denominator and } \\
\text { others }\end{array}$ \\
\hline $\begin{array}{l}\text { Conversational } \\
\text { phraseological units }\end{array}$ & $\begin{array}{l}\text { are used in lively, easy speech } \\
\text { (mainly oral), give it special } \\
\text { expressiveness }\end{array}$ & $\begin{array}{l}\text { did not see in the eyes, see } \\
\text { through, do not cherish the } \\
\text { soul, play spillikins and } \\
\text { others }\end{array}$ \\
\hline $\begin{array}{l}\text { Vernacular } \\
\text { phraseological units }\end{array}$ & $\begin{array}{l}\text { have a more reduced stylistic } \\
\text { character than colloquial ones, are } \\
\text { characterized by pronounced } \\
\text { emotionality and often have a } \\
\text { negative connotation }\end{array}$ & $\begin{array}{l}\text { play the fool, pea jester, } \\
\text { kick it in the neck, God } \\
\text { knows, rub glasses, rub } \\
\text { sides and others }\end{array}$ \\
\hline
\end{tabular}

The semantic structure of a phraseological unit, unlike a separate word, is characterized by a high specific gravity of connotative elements that are leading in the expression by the speaker (or the writer) of a subjective attitude to objective reality, that, we believe, determines the nature of the statement figurative basis, the stylistic interpretation of its constituent lexemes, gives an assessment, conveys emotions and a complex range of relationships to the speech subject.

The human society constantly have the needs for new types of products, and new technological processes are the key to solving this problem.

Pay attention that the phraseological unit "the key to solve the problem" not only introduces a scientific information but also reflects the exclusivity, according to the author, of the chosen method.

The main goal in the teaching of Russian as a foreign language is to teach foreigners to speak Russian as the means of communication and mastering a specialty. Observations show that phraseological units can be used in a popular science text both in untransformed (without changing semantics and structure) and in a transformed (with a change in semantics and structure) form, that reflects their stylistic and structural-semantic specificity. Most often, terminological attributive combinations of words with a prepositive definition of a non-idiomatic character are used in scientific texts $[3,4,6,8,9]$, i.e the phraseological units with terminological semantics (keywords, passive balance), correlated with definitions capable to convey a holistic concept and function in a scientific text as ready-made linguistic units, and phraseological units, common to all book styles (to a certain extent, fundamental changes), serving to explain of scientific reasoning or conclusion. The first type of phraseological units, represented mainly by formations of a material nature, does not allow variable or synonymous lexeme substitutions in its composition, is characterized by the unambiguity of the attributive definition and structural cohesion:

The article describes the method for calculating the strength and geometric characteristics of a fixed seine wing with a rigid frame and its elements: dead anchors, piles, etc.

The attributive combinations "a rigid frame" and "a dead anchor" in this example take on the semantic load of the whole phrase - replacing them with other lexemes will lead to information inaccuracy. 
Phraseological units, common to all book styles, as a rule, represented by verbalsubstantive unities (to show in a favorable light, to climb to the top), serve to a greater extent to clarify the meaningful block of the statement:

Optimization of design solutions of technical objects is widespread and is aimed at obtaining more economical solutions. The expediency of the structural solutions optimizing of building structures is also obvious as when making optimal decisions, construction costs can be significantly reduced [15].

Expressions, similar to phrases "widespread" and "decision-making" in a scientific text are endowed with semantic duality: they explain the content of scientific filling and expand an expressive informativeness due to emotional increment, which affects not so much the rational-logical, but the expressive-figurative component of the context, that determines one of the functional properties of phraseological units of this type. Moreover, such linguistic signs can vary in a lexical and grammatical filling:

A number of conditions are debatable, which aims to draw the attention of the scientific community to the problem posed.

Phraseological units with a weakened sematic meaning "to bear character", "to attract attention" are able to be replaced by their structurally unrelated (characterized) or related (arousing interest) verbal synonyms.

Such structural mobility of phraseological units, we believe, is a constant source of renewal of their expressiveness. On the other hand, although synonymy does not lead to the destruction of the integrity of the phraseological unit meaning, (since the general semantic core retains its stability), but its semantic form, undergoing contextual modifications, has some changes:

When speaking about force, we mean the force applied at the center of pressure.

If in this example the phraseological unit "have in mind" is replaced by the lexeme "to mean", then some subtext meanings can be erased (want to say, take note of, be considered ...) and new meanings will be added (speak allegorically, hint).

When determining the specifics of the phraseological meaning of such lexemes, it is necessary to take into account those elements of the linguistic structure that are directly involved in the implementation of the phraseological unit meaning, which has a component correlation (or non-correlation) and reflects the varying degrees of participation of the initial denotative meaning in the final meaningful interpretation, which is influenced by adding sense process ... As a result, not a sum of meanings is obtained, but a new sense, which leads to the complexity of its interpretation:

The represented setting refers to the butt one and, unlike other known similar wares, provides for the simultaneous stacking of the binder and the connecting element.

The features of the functioning of the indicated lexemes without changing the semantics and structure are due to their motivation: the brighter the semantic two-planarity, the more informative the volume of their content. Accordingly, when functioning of phraseological units, expressive informativeness is realized in semantic and emotional increments that affect both the rational-logical and expressive-figurative content of the context. In this regard, the specificity of the semantic structure of phraseological units depends on the complexity of an adequate understanding of their meaning by foreigners. Here is a number of examples of phraseological units that are most intensively used in technical mechanical engineering texts: to get out of the situation, in a sense, lead to a violation, take as a unit, take into account the meaning, hypothesize, exist as, occur on research, make an exception, take into account the meaning, component, etc.

Let us dwell on some methodological techniques of semantization of these and other scientific phraseological units and carry out a linguistic analysis of phraseological units functioning in a popular scientific text in order to use its results in further practical work in a foreign language audience. 
1. Acquaintance of students with the block of standards, under which, according to V. G. Kostomarov and E.M., Vereshchagin, we understand the expressions which are most often used in a written scientific text and fixed in a speech practice under the same semantics [4]:

To solve many problems, it is necessary to modernize all branches of mechanical engineering at once. But neither financial nor human resources are enough for this. That is why the main task can be considered a choice of priority sectors to be assisted:

In this example a lot of standard phraseologically related expressions are used that introduce information parts and determine not only the logicality and consistency of presentation, but also, conveying extralinguistic factors, reflect the richness of the language and save efforts which speed up and facilitates the process of scientific communicative interaction.

2. Demonstration of the conceptual component of the phraseological unit, its language veil.

Phraseological units, as a rule, are a multi-layered semantic syntaxeme, endowed with both explicit and implicit meaning at the same time: their pictorial shell plays an important role in the implementation of the communication pragmatic goals:

Due to the fact that the current environmental situation leaves much to be desired, the use of environmentally friendly materials in mechanical engineering will be timely and advisable.

The phraseological unit "leaves much to be desired" is based on the author's intention to influence the addressee of his speech in a certain way: to "impose" a personally marked position and induce a certain action, which proves the fact that the phraseological unit contains both communicative and informational and pragmatic content, acting as mediator of ideology, conditioned by the intention of the speaker, underlying a specific communication, and orienting recipient's ideological position at his certain life stage. therefore, a phraseological unit is able to reflect an individual and collective consciousness and turn them into an objective fact.

3. Disclosure of a phraseological unit meaning through a synonym, provided large semantic identification, which does not allow to break a content side: "to be popular" to be in demand, "to give an idea" - to show, "touch the question" - to speak, etc.

It should be said that the synonymization of such units simplifies their meaning: as the semantic volume of the phraseological unit does not coincide with the semantic volume of the synonym word; the latter is devoid of figurative meaning, connotative, an emotionally expressive and stylistic focus, which are characteristic of phraseological units.

4. Using the way of description in cases where it is not possible to convey the meaning of a phraseological unit by an identifier word. An interpretation with the help of a simple or complex description underlies in all phraseological dictionaries, which also indicate some thematic and normative-stylistic restrictions, knowing this will help to avoid mistakes typical for foreigners of using phraseological units in an unusual context for them.

5. Using a detailed commenting method by the language means of the student's native language, especially at the elementary training stage. But the use of word-by-word translation is permissible only if there are absolute equivalents of the defined phraseological unit in the student's native language, otherwise it can lead to the loss of meaning.

6. Involvement of the semantic context, which serves as an actualizer of the meaning; it should be minimal in volume, not contain any additional difficulties, and at the same time it should be sufficient to determine the meaning of the phraseological unit. 
The proposed methods of phraseological units semantization in a foreign audience by speech and non-speech means indicate the dependence of their semantics on reality, the place and purpose of the contextual use.

\section{Discussion}

Scientific literature review on the issue under study, in particular about the functions of phraseological units in scientific texts, is still open. If we follow to V.V. Vinogradov's points of view, describing phraseological adhesions and unity, as well as N.M. Shansky, who studied the correlation both semantic and grammatical plans of phraseological lexemes, then we can say that the designated linguistic units represent a block of standardized flares, reflecting extralinguistic factors: they save speech efforts and facilitate communication. These properties and functions of phraseological units made them a special type of veiled transmission of the author's self-position (including in a scientific text), which has recently become the object of attention of such linguists as Kravchenko E.V., Sokur I.O., Nikolenko OV, Zuga OV, Zlivko SD, who say that the nature of phraseological units is suggestive, since, in addition to direct nomination, they also convey a subjective subtext $[9,11,12,13,14]$ and form a personal narrative plan [8].

Such a scientific interpretation of phraseological units make us to reconsider teaching methods in any branch of science, and especially the methodology of Russian as a foreign language and its scientific style of speech. Steps in this direction were taken in the works of Ya.V. Poluyan, Yu.N. Farzonin, O. V Zuga, S. D. Zlivko [8, 9. 13] and others when creating a communicatively oriented grammar of an utterance. The aforementioned methodologists are inclined to believe that phraseological units expand a meaningful filling of a scientific phrase and become its pragmatic actualizer.

Taking this into account, the authors of this article prove that a phraseological unit in the scientific context is capable of influencing human consciousness when interpreting the content side of what is read (or orally perceived), therefore it is a material expression of the subjective and objective.

\section{Conclusion}

An analysis of the usual use of phraseology in a popular science text allows us to conclude that these lexemes are presented in them quite widely, and features of their functioning are determined by the influence of the subtext meaning underlying the creation of the designated units. When they are semantized for presentation to a foreign audience, it is necessary to take into account the specifics of their use in a scientific text, where the disclosure of their semantic meaning is determined comprehensively, taking into account the analysis of the use, type and structural-semantic category. The meaningful subtext, contained in the phraseological unit and represented in the scientific text by the veiled imperative, affects the addressee's worldview and passes from an internal motivation to an external one. This characteristic of phraseological units causes necessity to study them by foreign students in the scientific style of speech class and mastering the skills of their using, as among foreign students the level of speech-perceiving and speech-producing skills development that are necessary for them in connection with communication needs in the educational and professional sphere depends on a correct understanding of the structural necessity and meaningful filling of the language unit.

\section{References}


1. B. Strickland, M. Fisher, F. Keil, et al., Cognition, 133(1), 249-261 (2014)

2. V. Zinatullin, E. Chibisova, Philological sciences. Questions of theory and practice, 2(4), 129-133 (2011)

3. E. Borisova, Questions of linguistics, 2, 113-121 (2011)

4. M.Adam, A Handbook of Functional Sentence Perspective (FSP in Theory and Practice), Pejiagpgicka fakulta Masarykoya uniyerzita, 98 (2017)

5. T.A. Vorobyova, Bulletin of the Cherepovets State University, 14, (2013)

6. O.N. Guseva, Phraseology of scientific and business speech. Proceedings of VSTU. Series 5. Political science, philosophy, history, philology, 5, (2014)

7. V. Zusman, Literary Issues, 2, 3-29 (2013)

8. O.V. Zuga, S.D. Zlivko, In the world of scientific discovery (2014)

9. Yu. Varzonin, A rhetorical model: worldview, ethics, communication. Language, culture and society in the humanitarian paradigm: A collection of papers, M. Tver, 7$12(2015)$

10. O. Nikolenko, Semantic variation in complex sentences with homogeneously collateral sub-clauses in the Russian language: PhD Thesis in Philology (Rostov-on-Don, 158, 2011)

11. O.V. Nikolenko, A.V. Belozerova, N.V. Sumina, E.Y. Shapovalova, Parcelled phrases in the aspect of business communication "Breakthrough Technologies and Communications in Industry". International Scientific Practical Conference. Volgograd, Russian Federation (2018)

12. O. Nikolenko, O. Zakharchuk, L. Babakova, B. Morenko. The 'I' of the author and its persuasive function (as exemplified by the complex sentence with homogeneously collateral sub clauses). The International Scientific and Practical Conference Current Issues of Linguistics and Didactics: The Interdisciplinary Approach in Humanities and Social Sciences, SHS Web of Conferences, 69, 00081 (2019)

13. Y.V. Poluyan, Student electronic scientific journal, 38, (2020)

14. I.O. Sokur, Lexical and stylistic originality of phraseological units in a scientific text. Corporate research of Slavic languages and literatures, In memory of academician Leonid Bulakhovsky.Moscow, 12, (2010).

15. V.V. Chekmarev, Technology of mechanical engineering: a short course of lectures for third-year students of the direction of preparation 03.03.06 "Agroengineering" of the Federal State Budgetary Educational Institution of Higher Education "Saratov GAU". Saratov (2016) 